\title{
Combining ability of carrot (Daucus carota L.) lines and heritability of yield and its quality components
}

Barbara Jagosz

\author{
Department of Genetics, Plant Breeding and Seed Science \\ University of Agriculture in Krakow \\ 29 Listopada 54, 31-425 Krakow, Poland
}

\begin{abstract}
The purpose of this research was to investigate the combining ability of inbred lines in terms of traits important for the development of hybrid carrot cultivars with high yields and better root quality. The experimental plant material consisted of 15 inbred lines that were crossed in an incomplete diallel design to produce 34 hybrids. It was observed that the variation of general combining ability (GCA), specific combining ability (SCA) and reciprocal effects (RE) were significant for all of the tested characters, except SCA for sugars. Among the tested lines, the RFO had the most positive GCA for the yield; at the some time, the RFO line had negative GCA for carotenes and dry matter content. A significant positive GCA was found for all traits, except monosaccharides and nitrates, for the 2163 line. Most of the crosses based on the RFO and 2163 lines yielded well; additionally, the hybrids based on 2163 presented high levels of quality characters. The ratio of GCA:SCA indicated that the quality traits were mainly affected by additive gene effects, but the yield was controlled more by non-additive gene effects. Heritability in a broad sense presented a higher environmental influence for yield than the quality characters of carrot roots.
\end{abstract}

Key words: GCA, inheritance, quantitative traits, reciprocal effect, SCA

\section{INTRODUCTION}

Carrot (Daucus carota L.), that is one of the most important dietary sources of provitamin A carotenes amongst vegetables, and can be grown almost anywhere in the world. Today, hybrids have replaced open-pollinated cultivars. Timin and Vasilevskii (1995), Suh et al. (1999) and Jagosz (2011) documented carrot hybrid breeding based on inbred lines, in which crossing resulted in a heterosis effect, mainly in the case of root yield. On the other hand, heterosis is very rare in the case of root quality traits, which was confirmed by Gauciene et al. (1999), Chira et al. (2008) and Jagosz
(2011). Significant heterosis is usually connected with a good combining ability of the lines. The production of inbred carrot lines by self-pollination is laborious and time-consuming, and requires the kind of attention that is typical in biennial, openpollinated vegetables, so knowledge of combining ability could be helpful in speeding up the selection of parents for hybrids (Peterson and Simon 1986, Rubatzky et al. 1999, Simon et al. 2008).

Knowledge about inheritance and the genetic basis of quantitative traits in European carrot is still incomplete. The literature reveals that little research has focused on studying the actions of genes in carrot. Duan et al. (1996) tested seven carrot lines 
and 12 hybrids from a diallel cross and indicated a high positive general combining ability for yield. Chandel et al. (1994) carried out wide-ranging genetic studies of five quality characters in carrot. They observed strong additive effects for ascorbic acid content and domination for dry matter and total sugar, while both additive and non-additive gene effects were significant for total soluble solids and $\beta$-carotene. Chandel et al. (1994) also revealed epistatic gene effects for all of the examined traits. Mazurkiewicz (1973) studied the heritability and genetic variability of morphologic traits in the first generation of self-pollination of carrot strains. He found that the traits subjected to selection that was tested for a long time presented a low heritability and genetic variability. The heritability and gene numbers in the inheritance of carotenoids were widely studied by Santos and Simon (2006). Testing two carrot crosses, they revealed broad-sense heritability ranging from $28-48 \%$ for carotenes and from $44-89 \%$ for lycopene and phytoene in one of the crosses. Traka-Mavrona (1996) obtained quite high heritability values $\left(h^{2}=0.42-0.86\right)$ for skin quality, colour of shoulders, petiole attachment and root colour when observing some morphological traits of carrot. The research provided by Michalik et al. (1988) proved genetic differences in dry matter, sugar, and nitrate accumulation between the tested carrot lines. The study suggests a very high role of additive gene effects and high heritability for these compounds, especially nitrates, which are one of the undesirable compounds found in roots.

The objective of the present study was to estimate the combination ability and reciprocal effects of carrot inbred lines and crosses, considered for the development of high yield and better root quality characters, which are helpful in determining the appropriate parents and hybrids for the tested traits. Additionally, the presented research could contribute to the development of knowledge about the genetic basis and inheritance of quantitative carrot traits. The thorough study of carrot gene interaction will facilitate breeding programs aimed at obtaining superior crosses. Basic knowledge of the heritability and combining ability of lines could also be very important in reducing the costs and time of carrot breeding.

\section{MATERIAL AND METHODS}

Seven cytoplasmic male sterile (CMS) inbred lines A (six generations of back-crossing) representing the "brown anther type" 1028, 9370ba, and "petaloid type" 9370pet, 2874, 2158, 52274Fe,
2163, and their respective maintainer fertile lines B (seven generations of self-pollination) representing 1028, 9370, 2874, 2158, 52274Fe, 2163 and two fertile lines C (OZ and RFO, seven generations of self-pollination) used only as father lines, were crossed in an incomplete diallel fashion (Tab. 1). Diallel crosses resulted in seeds for 34 carrot hybrids. The crosses were provided from the greenhouse of breeding company PHRO in Krzeszowice, Poland. The breeders did not reveal the pedigree of the lines. Using carrot root shape classification by Simon et al. (2008), most of the lines were of the "Nantes" type, except OZ and RFO, which were classified as "Berlicum" and "Flakkee" types, respectively. Additionally, three commercial carrot hybrid cultivars (Kalina, Kazan and Napoli) were tested as the control.

The field experiment was performed during two years in the Experimental Field of the Department of Genetics, Plant Breeding and Seed Science at Prusy near Krakow, in southern Poland. The testing field was managed following standard agricultural practices for carrot production under Polish conditions. The experimental design was a randomised complete block with four replications. The seeds of lines and hybrids $\left(120\right.$ seeds per $\left.\mathrm{m}^{2}\right)$ were sown at the turn of April and May, in 2-metre row plots spaced $65 \mathrm{~cm}$ apart. The plots were handharvested at the beginning of September.

The lines and their crosses were evaluated in field trials in four replications for yield characters such as weight of total and marketable yield $(\mathrm{kg} 10$ $\mathrm{m}^{-2}$ ). Roots with a diameter of $>2.5 \mathrm{~cm}$, with typical shape and colour, and without splits, diseases and bolting, were considered as the marketable yield.

Fifteen randomly chosen representative roots from each of the three replications, totalling 45 for each line and hybrid, were used to measure the traits determining root quality. The chemical analysis was based on the mixed tissue of the crushed roots of each replication. Carotenes (mg $100 \mathrm{~g}^{-1}$ f.w.) were measured using the spectrophotometric method (PN90/A-75101.12), total sugar and monosaccharides (\% f.w.) using the colorimetric method (PN90/A-75101.07) and nitrates (mg $\mathrm{KNO}_{3} \mathrm{~kg}^{-1}$ f.w.) using an ionoselective electrode (PN-90/A-75112). For dry matter (\% f.w.) determination, the following drying method was applied: two $10 \mathrm{~g}$ samples of each replication were dried at $65^{\circ} \mathrm{C}$ for $16 \mathrm{~h}$, then at $95^{\circ} \mathrm{C}$ for one hour.

The results for yield and quality characters in both years of the study were comparable, so they were subjected to a general analysis of 
Table 1. Schematic of the incomplete diallel cross design used in the experiments

\begin{tabular}{|c|c|c|c|c|c|c|c|}
\hline \multirow[b]{2}{*}{ Paternal lines } & \multicolumn{7}{|c|}{ Maternal lines } \\
\hline & $1028 \mathrm{~A}$ & $9370 \mathrm{ba} \mathrm{A}$ & 9370pet A & $2874 \mathrm{~A}$ & $2158 \mathrm{~A}$ & $52274 \mathrm{Fe} \mathrm{A}$ & $2163 \mathrm{~A}$ \\
\hline $1028 \mathrm{~B}$ & & $x^{*}$ & & $x^{*}$ & & & $x^{*}$ \\
\hline $9370 \mathrm{~B}$ & $\times$ & & & $x^{*}$ & $x^{*}$ & $x^{*}$ & $x^{*}$ \\
\hline $2874 \mathrm{~B}$ & $x$ & $x$ & & & & & $\times *$ \\
\hline $2158 \mathrm{~B}$ & & $x$ & & & & & $x^{*}$ \\
\hline 52274Fe B & $\times$ & $x$ & $\times$ & $x$ & & & \\
\hline $2163 \mathrm{~B}$ & $x$ & $x$ & $x$ & $x$ & $x$ & & \\
\hline $\mathrm{OZC}$ & & $x$ & $x$ & $x$ & $x$ & $x$ & $x$ \\
\hline RFO C & $x$ & & $x$ & $x$ & $x$ & $x$ & $x$ \\
\hline
\end{tabular}

$\times$ Direct cross; $\times *$ Reciprocal cross

Table 2. Performance of parental lines and their crosses for yield and quality traits

\begin{tabular}{|c|c|c|c|c|c|c|c|c|}
\hline \multicolumn{2}{|c|}{ Lines and crosses } & $\begin{array}{c}\text { Total } \\
\text { yield } \\
\mathrm{kg} 10 \mathrm{~m}^{-2}\end{array}$ & $\begin{array}{c}\text { Marketable } \\
\text { yield } \\
\mathrm{kg} 10 \mathrm{~m}^{-2}\end{array}$ & $\begin{array}{l}\text { Carotenes } \\
\text { mg } 100 \mathrm{~g}^{-1} \text { f.w. }\end{array}$ & $\begin{array}{c}\text { Dry } \\
\text { matter } \\
\% \text { f.w. }\end{array}$ & $\begin{array}{c}\text { Total } \\
\text { sugar } \\
\% \text { f.w. }\end{array}$ & $\begin{array}{c}\text { Mono- } \\
\text { saccharides } \\
\text { \% f.w. }\end{array}$ & $\begin{array}{c}\text { Nitrates } \\
\mathrm{mg} \mathrm{KNO}_{3} \mathrm{~kg}^{-1} \text { f.w. }\end{array}$ \\
\hline \multicolumn{9}{|c|}{ Parents } \\
\hline \multicolumn{2}{|l|}{$1028 \mathrm{~A}$} & $42.6 \mathrm{~b}-\mathrm{e}^{1}$ & $30.2 a^{a}-c^{1}$ & $19.4{\mathrm{a}-\mathrm{d}^{1}}^{1}$ & 16.9 n.s. $^{2}$ & 9.2 n.s. $^{2}$ & $1.8 \mathrm{~cd}^{1}$ & $28 \mathrm{ab}^{1}$ \\
\hline \multicolumn{2}{|l|}{1028 B } & $36.0 \mathrm{c}-\mathrm{e}$ & $18.9 \mathrm{~cd}$ & $17.8 \mathrm{~b}-\mathrm{d}$ & 16.7 n.s. & 9.3 n.s. & $2.4 \mathrm{bc}$ & $32 \mathrm{ab}$ \\
\hline \multicolumn{2}{|l|}{$2158 \mathrm{~A}$} & 48.6 a-d & 29.3 a-c & $23.1 \mathrm{a}$ & 14.9 n.s. & 7.8 n.s. & $1.5 \mathrm{~d}$ & $22 \mathrm{a}$ \\
\hline \multicolumn{2}{|l|}{$2158 \mathrm{~B}$} & $30.5 \mathrm{e}$ & $14.9 \mathrm{~d}$ & $20.3 \mathrm{a}-\mathrm{c}$ & 15.0 n.s. & 8.9 n.s. & $1.9 \mathrm{~cd}$ & $25 \mathrm{ab}$ \\
\hline \multicolumn{2}{|l|}{$2163 \mathrm{~A}$} & 59.6 a & $31.8 \mathrm{ab}$ & 20.7 a-c & 14.7 n.s. & 8.6 n.s. & $1.6 \mathrm{~d}$ & $20 \mathrm{a}$ \\
\hline \multicolumn{2}{|l|}{2163 B } & $52.1 \mathrm{ab}$ & 28.0 a-c & $19.1 \mathrm{a}-\mathrm{d}$ & 13.9 n.s. & 8.3 n.s. & $2.0 \mathrm{~cd}$ & 45 a-c \\
\hline \multicolumn{2}{|l|}{$2874 \mathrm{~A}$} & 37.1 b-e & $21.3 \mathrm{a}-\mathrm{d}$ & $23.7 \mathrm{a}$ & 16.7 n.s. & 9.2 n.s. & $1.8 \mathrm{~cd}$ & $25 \mathrm{ab}$ \\
\hline \multicolumn{2}{|l|}{2874 B } & $42.0 \quad b-e$ & 26.9 a-d & $22.3 \mathrm{ab}$ & 16.4 n.s. & 9.1 n.s. & $2.1 \mathrm{~cd}$ & 23 a \\
\hline \multicolumn{2}{|c|}{$52274 \mathrm{Fe} \mathrm{A}$} & $33.9 \mathrm{de}$ & $23.3 \mathrm{a}-\mathrm{d}$ & $15.3 \mathrm{~d}$ & 14.7 n.s. & 8.6 n.s. & $3.4 \mathrm{a}$ & $47 \mathrm{a}-\mathrm{c}$ \\
\hline \multicolumn{2}{|c|}{$52274 \mathrm{Fe} \mathrm{B}$} & 34.7 c-e & 26.4 a-d & $15.7 \mathrm{~cd}$ & 14.3 n.s. & 7.9 n.s. & $2.8 \mathrm{ab}$ & $116 \mathrm{~d}$ \\
\hline \multicolumn{2}{|l|}{$9370 \mathrm{ba} \mathrm{A}$} & 42.8 b-e & 28.1 a-c & 20.8 a-c & 14.7 n.s. & 8.8 n.s. & $1.9 \mathrm{~cd}$ & $51 \mathrm{bc}$ \\
\hline \multicolumn{2}{|l|}{ 9370pet A } & $41.1 \mathrm{~b}-\mathrm{e}$ & 26.6 a-d & $21.9 \mathrm{ab}$ & 14.9 n.s. & 8.6 n.s. & $2.2 \mathrm{~cd}$ & $31 \mathrm{ab}$ \\
\hline \multicolumn{2}{|l|}{9370 B } & $32.4 \mathrm{e}$ & 20.7 b-d & $20.3 \mathrm{a}-\mathrm{c}$ & 15.2 n.s. & 8.0 n.s. & $1.6 \mathrm{~d}$ & $78 \mathrm{c}$ \\
\hline \multicolumn{2}{|l|}{$\mathrm{OZ} \mathrm{C}$} & 49.8 a-c & $32.8 \mathrm{a}$ & 20.5 a-c & 14.2 n.s. & 7.6 n.s. & $1.6 \mathrm{~d}$ & $31 \mathrm{ab}$ \\
\hline \multicolumn{2}{|l|}{ RFO C } & $58.5 \mathrm{a}$ & $31.4 \mathrm{ab}$ & $20.1 \mathrm{a}-\mathrm{c}$ & 14.0 n.s. & 7.9 n.s. & $1.7 \mathrm{~d}$ & $38 \mathrm{ab}$ \\
\hline \multicolumn{9}{|c|}{ Hybrids } \\
\hline \multirow{2}{*}{1028} & mean & 66.7 & 41.4 & 19.2 & 15.1 & 8.6 & 2.0 & 40 \\
\hline & range & $47.0-92.6$ & $30.0-52.5$ & $17.1-22.3$ & $14.0-16.5$ & $8.2-9.2$ & $1.7-2.4$ & $19-71$ \\
\hline \multirow{2}{*}{2158} & mean & 68.0 & 43.0 & 20.8 & 14.5 & 8.2 & 1.9 & 28 \\
\hline & range & $48.3-78.0$ & $25.3-58.3$ & $15.5-23.6$ & $12.4-15.8$ & $7.3-8.7$ & $1.6-2.3$ & $20-40$ \\
\hline \multirow{2}{*}{2163} & mean & 64.7 & 40.2 & 21.1 & 15.1 & 8.7 & 1.8 & 33 \\
\hline & range & $44.0-78.0$ & $26.0-58.3$ & $18.3-23.6$ & $12.8-15.9$ & $8.2-9.2$ & $1.2-2.4$ & $21-49$ \\
\hline \multirow{2}{*}{2874} & mean & 63.4 & 40.3 & 21.2 & 15.0 & 8.6 & 1.9 & 35 \\
\hline & range & $47.3-82.2$ & $27.0-55.5$ & $17.7-23.4$ & $14.1-16.5$ & $8.0-9.2$ & $1.5-2.3$ & $17-65$ \\
\hline \multirow{2}{*}{$52274 \mathrm{Fe}$} & mean & 66.1 & 40.3 & 17.0 & 13.9 & 8.1 & 2.4 & 58 \\
\hline & range & $47.5-87.0$ & $30.0-62.9$ & $12.3-19.0$ & $10.8-15.3$ & $6.2-8.8$ & $2.0-2.8$ & $25-158$ \\
\hline \multirow{2}{*}{$9370 \mathrm{ba}$} & mean & 61.6 & 38.0 & 18.9 & 14.2 & 8.1 & 2.0 & 57 \\
\hline & range & $44.0-83.7$ & $26.0-52.1$ & $12.3-23.5$ & $10.8-15.4$ & $6.2-8.8$ & $1.2-2.8$ & $20-158$ \\
\hline \multirow{2}{*}{ 9370pet } & mean & 66.7 & 42.5 & 18.7 & 13.5 & 7.9 & 2.0 & 63 \\
\hline & range & $47.5-93.4$ & $30.0-60.8$ & $12.3-23.5$ & $10.8-14.8$ & $6.2-8.8$ & $1.2-2.3$ & $21-158$ \\
\hline \multirow{2}{*}{$\mathrm{OZ}$} & mean & 56.8 & 33.9 & 20.8 & 14.5 & 8.4 & 1.8 & 44 \\
\hline & range & $47.3-70.2$ & $25.3-45.2$ & $19.0-22.7$ & $13.4-15.3$ & $7.6-9.2$ & $1.6-2.1$ & $17-77$ \\
\hline & mean & 82.8 & 50.3 & 18.6 & 14.0 & 8.2 & 2.1 & 45 \\
\hline RFU & range & $65.0-92.6$ & $27.9-63.0$ & $15.8-21.9$ & $12.7-15.1$ & $7.5-8.7$ & $1.9-2.6$ & $26-80$ \\
\hline & mean & 86.1 & 46.2 & 20.0 & 13.1 & 8.0 & 2.5 & 86 \\
\hline Control $^{3}$ & range & $63.0-100.5$ & $29.2-72.8$ & $16.7-21.6$ & $11.8-14.1$ & 7.9-8.3 & $2.0-3.0$ & $25-112$ \\
\hline
\end{tabular}

${ }^{1}$ Values marked with the same letters do not differ significantly at $\mathrm{p}=0.05$

${ }^{2}$ Not significant at $p=0.05$

${ }^{3}$ Mean of three commercial hybrid cultivars: Kamila, Kazan and Napoli 
variance (ANOVA) as the mean of two years. The significant differences were calculated using the Duncan test at a significance level of $p=0.05$. An analysis of the general (GCA) and specific (SCA) combining ability, reciprocal effects (RE), as well as heritability in a broad sense and the variability coefficient of yield and quality traits was carried out using DIALLEL software (Department of Experimental Design and Bioinformatics, Warsaw University of Life Sciences, Warsaw, Poland). The significance of GCA, SCA and RE were assessed at a $\mathrm{p}=0.05$ probability level. The GCA:SCA ratio was calculated using the ratios of the mean squares for GCA and SCA.

\section{RESULTS}

The mean values of the hybrids for the total as well as the marketable yield of roots were usually higher than those of the parents (Tab. 2). However, the means for quality characters were usually similar between the lines and hybrids. Some of the crosses presented a higher total, as well as marketable yield, and most of them showed higher level of carotenes, dry matter and total sugar, as compared to the control. The majority of the crosses based on the line 2163 presented high levels of carotenes, dry matter and total sugar, and low nitrates, where low content is desirable for consumers. Additionally, two $-2158 \times 2163$ and $2163 \times 2874-$ also showed quite a high yield of roots. Most of the hybrids based on the RFO line were the most fertile, but they presented rather poor contents of quality compounds.

Analyses of variance of both GCA and SCA for the yield, as well as quality traits such as carotenes, dry matter and nitrates, were significant (Tab. 3). For total sugar and monosaccharides, significant differences were detected only in GCA, not in SCA. In most cases, GCA variances were larger than SCA variances, so the ratio of GCA to SCA mean squares was greater then one (ranging from 1.17 for total yield to 9.40 for monosaccharides) for most of the traits except marketable yield, for which the GCA:SCA mean squares ratio was 0.51. Finally,

Table 3. Mean squares for general and specific combining ability and reciprocal effects for yield and quality traits

\begin{tabular}{|c|c|c|c|c|c|c|c|c|c|}
\hline \multirow{2}{*}{ Source of variation } & \multicolumn{3}{|c|}{ Yield traits ${ }^{1}$} & \multicolumn{6}{|c|}{ Quality traits ${ }^{2}$} \\
\hline & $\mathrm{df}$ & TY & MY & $\mathrm{df}$ & $\mathrm{CC}$ & $\mathrm{DM}$ & $\mathrm{TS}$ & $\mathrm{MC}$ & $\mathrm{NC}$ \\
\hline GCA & 8 & $270.63^{*}$ & $70.91 *$ & 8 & $19.75^{*}$ & $2.58^{*}$ & $0.59 *$ & $0.47 *$ & $1066.67 *$ \\
\hline SCA & 25 & $231.56^{*}$ & $139.42 *$ & 25 & $2.82 *$ & $0.73^{*}$ & 0.19 & 0.05 & $354.60 *$ \\
\hline $\mathrm{RE}$ & 9 & $138.80^{*}$ & $79.20^{*}$ & 9 & $6.95^{*}$ & $1.62 *$ & $0.53^{*}$ & $0.14^{*}$ & $869.72 *$ \\
\hline Error & 126 & 0.84 & 0.94 & 84 & 1.05 & 0.22 & 0.16 & 0.06 & 185.17 \\
\hline GCA:SCA & & 1.17 & 0.51 & & 7.00 & 3.53 & 3.11 & 9.40 & 3.01 \\
\hline Heritability & & 0.05 & 0.00 & & 0.63 & 0.42 & 0.37 & 0.73 & 0.36 \\
\hline Variability coefficient & & 22.9 & 39.0 & & 8.9 & 5.6 & 8.4 & 21.2 & 57.1 \\
\hline
\end{tabular}

${ }^{1} \mathrm{TY}$ - total yield, MY - marketable yield

${ }^{2} \mathrm{C}$ - carotenes, DM - dry matter, TS - total sugar, $\mathrm{M}$ - monosaccharides, $\mathrm{N}$ - nitrates

$*$ Values marked with asterisks are significant at $\mathrm{p}=0.05$

Table 4. Estimates of general combining ability for yield and quality traits of nine parental carrot lines

\begin{tabular}{lccccccc}
\hline Lines & $\begin{array}{c}\text { Total } \\
\text { yield } \\
\mathrm{kg} 10 \mathrm{~m}^{-2}\end{array}$ & $\begin{array}{c}\text { Marketable } \\
\text { yield } \\
\mathrm{kg} \mathrm{10} \mathrm{m}^{-2}\end{array}$ & $\begin{array}{c}\text { Carotenes } \\
\mathrm{mg} \mathrm{100} \mathrm{g}^{-1} \text { f.w. }\end{array}$ & $\begin{array}{c}\text { Dry } \\
\text { matter } \\
\% \text { f.w. }\end{array}$ & $\begin{array}{c}\text { Total } \\
\text { sugar } \\
\% \text { f.w. }\end{array}$ & $\begin{array}{c}\text { Mono- } \\
\text { saccharides } \\
\% \text { f.w. }\end{array}$ & $\begin{array}{c}\text { Nitrates } \\
\mathrm{mg} \mathrm{KNO}_{3} \mathrm{~kg}^{-1} \text { f.w. }\end{array}$ \\
\hline 1028 A and B & -0.20 & $0.75^{*}$ & -0.54 & $0.69^{*}$ & $0.23^{*}$ & -0.02 & -4.38 \\
2158 A and B & 0.30 & $0.97^{*}$ & $1.21^{*}$ & 0.08 & -0.20 & -0.13 & $-13.71^{*}$ \\
2163 A and B & $2.43^{*}$ & $0.61^{*}$ & $0.77^{*}$ & $0.31^{*}$ & $0.26^{*}$ & $-0.13^{*}$ & $-8.58^{*}$ \\
2874 A and B & $-3.06^{*}$ & $-1.24^{*}$ & $1.82^{*}$ & $0.58^{*}$ & $0.28^{*}$ & -0.07 & $-8.50^{*}$ \\
52274Fe A and B & $-1.85^{*}$ & $-1.33^{*}$ & $-2.60^{*}$ & $-0.40^{*}$ & -0.12 & $0.52^{*}$ & $9.13^{*}$ \\
9370ba A and B & $-1.87^{*}$ & $-1.25^{*}$ & $-0.71^{*}$ & $-0.50^{*}$ & $-0.23^{*}$ & 0.03 & $16.21^{*}$ \\
9370pet A and B & $-4.07^{*}$ & -0.34 & -0.13 & $-0.36^{*}$ & -0.01 & 0.02 & 6.92 \\
OZ C & $-4.40^{*}$ & $-3.37^{*}$ & $0.66^{*}$ & -0.12 & -0.16 & $-0.18^{*}$ & -0.63 \\
RFO C & $12.78^{*}$ & $5.97^{*}$ & $-0.78^{*}$ & $-0.60^{*}$ & -0.22 & 0.00 & 3.63 \\
\hline
\end{tabular}

$*$ Values marked with asterisks are significant at $\mathrm{p}=0.05$ 
it was observed that the mean squares of RE were significant for all of the evaluated characters.

Significant differences at GCA were obtained for all of the lines, positive or negative, depending on the trait (Tab. 4). The RFO line had the most positive GCA amongst the parents for the yield; however, it simultaneously had negative GCA for carotenes and dry matter. A high positive GCA for yield was estimated for the 2163 line, which additionally showed positive GCA for carotenes, dry matter and total sugar, and negative for nitrates and monosaccharides. Significantly positive GCA for marketable yield was determined for the 2158 and 1028 lines; the former also had positive GCA for carotenes and negative for nitrates. The 1028 line had positive GCA for both dry matter and total sugar. One of the tested lines, 2874, presented negative GCA for yield, but positive for carotenes, dry matter and total sugar, and negative for nitrates.

Table 5. Specific combining ability and reciprocal effects for yield and quality traits of carrot hybrids

\begin{tabular}{|c|c|c|c|c|c|c|c|}
\hline Crosses & $\begin{array}{c}\text { Total } \\
\text { yield } \\
\mathrm{kg} 10 \mathrm{~m}^{-2}\end{array}$ & $\begin{array}{c}\text { Marketable } \\
\text { yield } \\
\mathrm{kg} 10 \mathrm{~m}^{-2}\end{array}$ & $\begin{array}{c}\text { Carotenes } \\
\text { mg } 100 \mathrm{~g}^{-1} \text { f.w. }\end{array}$ & $\begin{array}{c}\text { Dry } \\
\text { matter } \\
\% \text { f.w. }\end{array}$ & $\begin{array}{c}\text { Total } \\
\text { sugar } \\
\% \text { f.w. }\end{array}$ & $\begin{array}{c}\text { Mono- } \\
\text { saccharides } \\
\text { \% f.w. }\end{array}$ & $\begin{array}{c}\text { Nitrates } \\
\text { mg KNO}{ }_{3} \mathrm{~kg}^{-1} \text { f.w. }\end{array}$ \\
\hline \multicolumn{8}{|c|}{ Specific combining ability } \\
\hline $1028 \mathrm{~A} \times 2163 \mathrm{~B}$ & $6.99 *$ & $7.16^{*}$ & -0.63 & -0.18 & & & 6.61 \\
\hline $1028 \mathrm{~A} \times 2874 \mathrm{~B}$ & $7.62 *$ & $5.74 *$ & -1.13 & -0.34 & & & -0.97 \\
\hline $1028 \mathrm{~A} \times 52274 \mathrm{Fe} \mathrm{B}$ & $-7.00 *$ & $-6.14^{*}$ & $1.91 *$ & 0.14 & & & -13.10 \\
\hline $1028 \mathrm{~A} \times 9370 \mathrm{~B}$ & $-1.80^{*}$ & $-2.86^{*}$ & 0.57 & -0.15 & & & 6.32 \\
\hline $1028 \mathrm{~A} \times \mathrm{RFO} \mathrm{C}$ & $18.43^{*}$ & $5.07 *$ & 0.74 & -0.54 & & & -1.61 \\
\hline $2158 \mathrm{~A} \times 2163 \mathrm{~B}$ & $6.30^{*}$ & $8.83^{*}$ & $1.31^{*}$ & 0.45 & & & 5.44 \\
\hline $2158 \mathrm{~A} \times \mathrm{OZC}$ & $-9.13^{*}$ & $-10.48^{*}$ & 1.02 & 0.70 & & & 12.98 \\
\hline $2158 \mathrm{~A} \times \mathrm{RFO} \mathrm{C}$ & $1.80^{*}$ & -0.36 & 0.19 & -0.60 & & & -0.28 \\
\hline $2163 \mathrm{~A} \times \mathrm{OZC}$ & $10.61 *$ & $9.76^{*}$ & 0.80 & 0.38 & & & -2.14 \\
\hline $2163 \mathrm{~A} \times \mathrm{RFO} \mathrm{C}$ & $-11.76^{*}$ & $-16.86^{*}$ & -1.56 & 0.73 & & & -2.40 \\
\hline $2874 \mathrm{~A} \times 2163 \mathrm{~B}$ & 0.12 & -0.67 & 0.19 & -0.09 & & & 9.73 \\
\hline $2874 \mathrm{~A} \times 52274 \mathrm{Fe} \mathrm{B}$ & $11.99 *$ & $7.03^{*}$ & -0.92 & -0.75 & & & -6.98 \\
\hline $2874 \mathrm{~A} \times \mathrm{OZ} \mathrm{C}$ & $-6.81 *$ & $-6.58^{*}$ & 0.32 & -0.62 & & & -15.22 \\
\hline $2874 \mathrm{~A} \times \mathrm{RFO} \mathrm{C}$ & $10.97 *$ & $12.56^{*}$ & 0.98 & -0.04 & & & -10.48 \\
\hline $52274 \mathrm{Fe} \mathrm{A} \times \mathrm{OZ} \mathrm{C}$ & $9.68^{*}$ & $-2.74 *$ & 1.09 & $1.21 *$ & & & $-24.85^{*}$ \\
\hline $52274 \mathrm{Fe} \mathrm{A} \times \mathrm{RFO} \mathrm{C}$ & $14.56^{*}$ & $20.07 *$ & -0.63 & $-0.92 *$ & & & 7.89 \\
\hline $9370 \mathrm{ba} A \times 2158 \mathrm{~B}$ & $10.91 *$ & $7.44^{*}$ & $-2.74^{*}$ & $-0.65 *$ & & & $-19.85^{*}$ \\
\hline $9370 \mathrm{ba} \mathrm{A} \times 2163 \mathrm{~B}$ & $-9.75^{*}$ & $-8.34 *$ & $1.28^{*}$ & $0.68 *$ & & & -13.98 \\
\hline $9370 \mathrm{ba} \mathrm{A} \times 2874 \mathrm{~B}$ & $2.55^{*}$ & $2.84^{*}$ & 0.55 & 0.24 & & & 6.94 \\
\hline $9370 \mathrm{ba} \mathrm{A} \times 52274 \mathrm{Fe} \mathrm{B}$ & $13.39 *$ & $6.42 *$ & $-1.67 *$ & $-0.82 *$ & & & $33.31 *$ \\
\hline $9370 \mathrm{ba} \mathrm{A} \times \mathrm{OZ} \mathrm{C}$ & -0.62 & $4.26^{*}$ & -0.64 & -0.62 & & & 20.07 \\
\hline 9370 pet $A \times 2163 B$ & $7.37 *$ & $8.36^{*}$ & $-2.14^{*}$ & $-1.74 *$ & & & -2.69 \\
\hline 9370 pet $\mathrm{A} \times 52274 \mathrm{Fe} \mathrm{B}$ & $-8.18^{*}$ & $-6.54^{*}$ & 0.62 & 0.20 & & & -4.39 \\
\hline 9370pet $\mathrm{A} \times \mathrm{OZ} \mathrm{C}$ & $2.22 *$ & $3.08^{*}$ & -1.19 & -0.68 & & & $27.36^{*}$ \\
\hline 9370pet A $\times$ RFO C & $23.17 *$ & $16.94 *$ & $-1.88^{*}$ & 0.15 & & & $28.10^{*}$ \\
\hline \multicolumn{8}{|c|}{ Reciprocal effects } \\
\hline $2158 \mathrm{~A} \times 9370 \mathrm{~B}$ & $-1.33 *$ & $6.72 *$ & $-2.09^{*}$ & $-1.15^{*}$ & -0.43 & 0.21 & 4.00 \\
\hline $2163 \mathrm{~A} \times 1028 \mathrm{~B}$ & $6.23^{*}$ & $5.83^{*}$ & -0.89 & -0.40 & -0.45 & -0.13 & 5.00 \\
\hline $2163 \mathrm{~A} \times 2158 \mathrm{~B}$ & $-7.38 *$ & $-9.67 *$ & -0.48 & -0.29 & -0.17 & 0.07 & -1.50 \\
\hline $2163 \mathrm{~A} \times 2874 \mathrm{~B}$ & $12.62 *$ & $8.52 *$ & 0.52 & -0.07 & 0.17 & -0.08 & -5.00 \\
\hline $2163 \mathrm{~A} \times 9370 \mathrm{~B}$ & $8.35^{*}$ & $3.16^{*}$ & $2.31 *$ & 0.22 & 0.12 & $-0.59 *$ & -14.00 \\
\hline $2874 \mathrm{~A} \times 1028 \mathrm{~B}$ & $-3.54 *$ & $-4.31 *$ & $2.34 *$ & $0.93 *$ & 0.32 & -0.19 & -8.50 \\
\hline $2874 \mathrm{~A} \times 9370 \mathrm{~B}$ & $-4.30 *$ & $-4.25 *$ & $1.92 *$ & -0.12 & -0.40 & 0.27 & -9.00 \\
\hline $52274 \mathrm{Fe} \mathrm{A} \times 9370 \mathrm{~B}$ & $12.50^{*}$ & $6.45^{*}$ & $-2.58 *$ & $-2.07 *$ & $-1.28 *$ & -0.27 & $58.00^{*}$ \\
\hline $9370 \mathrm{ba} \mathrm{A} \times 1028 \mathrm{~B}$ & $-10.65^{*}$ & $-4.80 *$ & $-2.12 *$ & $0.71^{*}$ & 0.01 & -0.13 & -11.50 \\
\hline
\end{tabular}

*Explanations: see Table 4 
In most of the crosses $(68 \%)$ of the 25 tested in a diallel fashion, the lines exhibited positive SCA for both yield characters or at least for one of them (Tab. 5). Positive SCA for carotenes was recorded in the case of the lines where crossing resulted in three hybrids $(1028 \times 52274 \mathrm{Fe}, 9370 \mathrm{ba} \times 2163$, $2158 \times 2163$ ), whereas negative was found in the case of four hybrids. For dry matter, positive SCA was measured in $8 \%(9370 \mathrm{ba} \times 2163,52274 \mathrm{Fe} \times$ $\mathrm{OZ}$ ), and negative in $16 \%$ of the lines. Only two pairs of lines $(9370 \mathrm{ba} \times 2158,52274 \mathrm{Fe} \times \mathrm{OZ})$ exhibited negative SCA for nitrates.

Positive reciprocal influences for both total and marketable yield were calculated in four crosses $(52274 \mathrm{Fe} \times 9370,2163 \times 1028,2163 \times 9370,2163$ $\times 2874$ ) of the nine tested (Tab. 5). For the cross $2158 \times 9370$, positive RE was indicated only for marketable yield. The rest of the reciprocal crosses presented negative influences of cytoplasm for yield. For quality traits, positive RE was found to be significant in three crosses for carotenes, and in two for dry matter.

The broad sense heritability estimated for both total and marketable yield was very low and the amounts were 0.05 and 0.00 , respectively (Tab. $3)$. The heritability of quality characters was much higher, especially for monosaccharides (0.73) and carotenes (0.63). Heritability measured for dry matter, total sugar and nitrates was average and the amounts were $0.42,0.37$ and 0.36 , respectively.

The variability coefficient calculated for the total and marketable yield was $22.9 \%$ and $39.0 \%$, respectively (Tab. 3). For root quality components, the variability ranged from $5.6 \%$ for dry matter to $57.1 \%$ for nitrates. Quite low variability coefficients for total sugar $(8.4 \%)$, and carotenes $(8.9 \%)$, were estimated.

\section{DISCUSSION}

The main goal of the research was to obtain more information on the inheritance of quantitative characters of carrot and to identify the best parents for hybrids. Heterosis breeding is now the leading method for creating new varieties of many crop species. This method makes it possible to increase the value of quantitative traits of first-generation hybrids of carrots (Timin and Vasilevskii 1995, Suh et al. 1999, Jagosz 2011). In addition, the selection of breeding materials that accompanies the breeding process also improves carrot root quality traits (Michalik et al. 1988, Gauciene et al. 1999, Chira et al. 2008, Jagosz 2011).
The analyses of the GCA as well as SCA variances were significant, indicating both additive and non-additive genetic effects for yield. However, a low GCA:SCA mean squares ratio $(0.51)$ indicated the participation of non-additive effects in the inheritance of the marketable carrot yield. In addition, the GCA:SCA ratio was very close to one (1.17) for total yield, implying that both additive and non-additive gene effects were important. According to Duan et al. (1996), only GCA was significant for carrot yielding.

The quality components of carrot were mainly controlled by additive gene effects, which was confirmed by the high value $(3.01-9.40)$ of the balance between GCA:SCA. In the case of carotenes, dry matter and nitrates, both GCA and SCA variances were found to be significant. Chandel et al. (1994) also reported on the dominance of non-additive effects for dry matter and total sugar in carrot, which indicated that both additive and non-additive genes controlled total soluble solids and $\beta$-carotene. The predominance of additive gene effects for dry matter, sugar and nitrates (Michalik et al. 1988) and for ascorbic acid (Chandel et al. 1994) in carrot roots have been demonstrated. RE is an important component, especially when traits are maternally determined. RE was significant for all of the tested characters, therefore yield and root quality traits seemed to be controlled by maternal inheritance. Notably, the cytoplasm of maternal line 2163 showed positive effects for yield in most of the crosses.

The RFO line was the best general combiner but only for yield, whereas line 2163 was found to be a good general combiner for both yield and root quality characters. Usually, the crosses of parents with good performance also yielded good performance in hybrids for all of the traits, which confirmed the effectiveness of selection in carrot breeding material. However, SCA effects are very important for open-pollinated cultivars like carrot. The most promising specific combinations for all of the tested characters came from crosses including $2874 \times$ RFO $, 2158 \times 2163,2158 \times$ RFO, 2163 $\times 1028$ and $2163 \times$ OZ. Usually, lines with high positive GCA for yield produced crosses with high SCA for that trait. The same dependence was not observed for quality characters. These results were confirmed by Timin and Vasilevskii (1995), Suh et al. (1999) and Jagosz (2011), who found significant heterosis for yield of carrot hybrids, while mostly mid-parent values of quality compound content was 
confirmed by Gauciene et al. (1999), Chira et al. (2008) and Jagosz (2011).

The broad sense heritability values, close to zero, indicated a strong environmental influence and thus no influence of genetic factors for yield. On the other hand, high heritability was estimated for carotenes and monosaccharides -0.63 and 0.73 , respectively. Santos and Simon (2006) had observed a broad sense heritability ranging from 28 to $48 \%$ for carotenes in two tested crosses. Traka-Mavrona (1996), testing carrot root colour, estimated high heritability values $\left(\mathrm{h}^{2}=0.49-0.86\right)$. The presented carrot study showed limited environmental influence on dry matter, total sugar and nitrates. Research published by Michalik et al. (1988) also suggests a high heritability of these nutritional compounds. The estimation of the variability coefficient value indicates a stronger influence of the environment on carrot yielding than on quality traits, except monosaccharides and nitrates.

The presented combining ability and heritability study is one of the latest and the broadest in the case of carrot. The reported results suggest that both additive and non-additive gene effects played an important role in the inheritance of yield and quality components of carrot roots. Significant reciprocal differences for all of the tested characters suggest that cytoplasmic gene effects and their interaction with nuclear genes were also responsible in creating new hybrid carrot cultivars. The present research allows us to indicate which parents are good general combiners, as well as the best specific combinations for most of the tested traits. The information reported in this paper will be useful in selecting inbred carrot lines with high GCA before making specific crosses, which will allow a reduction in the time and costs of hybrid production. The results lead to the conclusion that there is still a large genetic base for the effective selection for most quantitative characters that are important in carrot breeding programmes. Hopefully, the carrot diallel study will also be useful for breeders of other vegetables species.

\section{REFERENCES}

Chandel K.S., Singh A.K., Rattan R.S., 1994. Genetical studies of quality traits in carrot (Daucus carota L.). Indian J. Genet. 54(4): 389-394.

Chira E., Sbirciog G., Badea R., 2008. Manifestation intensity of heterosis phenomenon for some chemical contents in some $\mathrm{F}_{1}$ carrot hybrids (Daucus carota L.). Bulletin UASVM, Horticulture 65(1): 465.
Duan Y., Wang Y., Ren X.Y., Du G.Q., 1996. Analysis of heterosis and combining ability for main yield characteristics in carrot. China Vegetables 2: 13-15.

Gauciene O., VišKelis P., Karkleliene R., 1999. Nutritional value of hybrids in relation to parental varieties of carrots. Umbelliferae Improvement Newsletter 9: 13-16.

JAGOSz B., 2011. The relationship between heterosis and genetic distances based on RAPD and AFLP markers in carrot. Plant Breeding 130: 574-579.

MazURKIEwicz Z., 1973. Heritability and genetic variability of morphologic characteristics in carrot (Daucus carota L.) var. Perfekcja. Biul. Warz. 14: 125-137.

Michalik B., Zabagıo A., Żukowska E., 1988. Nutritional value of hybrids in relation to parental lines of carrots. Hod. Roś. Aklim. i Nasien. 32(1/2): 251-254.

Peterson C.E., Simon P.W., 1986. Carrot breeding. In: Breeding vegetable crops. M.J. Basset (ed.), AVI, Westport, Connecticut: 321-356.

PN-90/A-75101.12., 1990. Fruit and vegetable products. Preparation of samples and testing methods. Determination of carotenoids and $\beta$-carotene content. Available online at http://enormy.pl/?m $=$ src\&idx $=$ ICS,0067.0080.X; cited on 30 Sept 2010.

PN-90/A-75101.07., 1990. Fruit and vegetable products. Preparation of samples and testing methods. Determination of sugar content and nonsugar extract. Available online at http://enormy. $\mathrm{pl} /$ ?m=src\&idx=ICS,0067.0080.X; cited on $30 \mathrm{Sept}$ 2010 .

PN-90/A-75112., 1992. Fruits, vegetables and derived products. Determination of nitrites and nitrates content. Available online at http://enormy.pl/?m $=$ src\&idx $=$ ICS,0067.0080.X; cited on 30 Sept 2010 .

Rubatzky V.E., Quiros C.F., Simon P.W., 1999. Carrots and related vegetable Umbelliferae. CABI Publishing, Cambridge.

Santos C.A.F., Simon P.W., 2006. Heritabilities and minimum gene number estimates of carrot carotenoids. Euphytica 151: 79-86.

Simon P.W., Freeman R.E., Vieira J.V., Boiteux L.S., Briard M., Nothnagel T., Michalik B., Kwon Y.S., 2008. Carrot. In: Handbook of plant breeding: Vegetables II: Fabaceae, Liliaceae, Solanaceae, and Umbelliferae. J. Prohens and F. Nuez (eds), Springer, New York: 327-357.

Suh Y.K., Youn G.H., Cho Y.H., PaeK K.Y., 1999. Expression of some quantitative and qualitative characters among breeding lines and their $\mathrm{F}_{1}$ hybrids in carrot. J. Korean Soc. Hort. Sci. 40: 697-701.

Timin N.I., VAsilevskiI V.A., 1995. Carrot lines for heterosis breeding using cytoplasmic male sterility (CMS). Kartofel i Ovoshchi 3: 27-28.

Traka-Mavrona E., 1996. Effects of competition on phenotypic expression and differentiation of five 
quality traits of carrot (Daucus carota L.) and their implications in breeding. Scientia Hort. 65: 335-340.

\section{ZDOLNOŚĆ KOMBINACYJNA LINII HODOWLANYCH MARCHWI (DAUCUS CAROTA L.) ORAZ ODZIEDZICZALNOŚĆ PLONU I JEGO CECH JAKOŚCIOWYCH}

Streszczenie: Celem badań była ocena zdolności kombinacyjnej wykorzystywanej w procesie tworzenia nowych mieszańcowych odmian marchwi charakteryzujących się wysokim plonem i jakością korzeni. Materiał badawczy stanowiło 15 linii wsobnych, w oparciu o które wykonano krzyżowania dialleliczne $\mathrm{w}$ niepełnym układzie, co pozwoliło na uzyskanie nasion dla 34 mieszańców $\mathrm{F}_{1}$. Badano plon oraz cechy określające jakość korzeni spichrzowych. Stwierdzono, że zarówno ogólna (GCA), jak i specyficzna (SCA) zdolność kombinacyjna oraz efekty krzyżowań odwrotnych (RE) były statystycznie istotne dla wszystkich badanych cech, z wyjątkiem SCA dla cukrów. Wśród badanych linii, RFO miała najbardziej pozytywną GCA dla plonu, ale negatywną dla karotenów i suchej masy. W przypadkulinii2163, znaczącąGCA oszacowano dla wszystkich cech, oprócz cukrów prostych. Większość kombinacji $\mathrm{F}_{1}$, wykonanych w oparciu o linie RFO i 2163, odznaczało się wysokim plonem korzeni. Dodatkowo, mieszańce oparte na linii 2163 charakteryzowały się także wysokim poziomem składników odżywczych. Stosunek średnich kwadratów GCA:SCA sugeruje, że cechy jakościowe były kontrolowane głównie przez geny addytywne, podczas gdy cechy plenności warunkowane były $\mathrm{w}$ przeważającym stopniu przez geny nieaddytywne. Współczynnik odziedziczalności wskazywał na większy wpływ czynników środowiskowych na plenność niż na jakość korzeni marchwi.

Received March 3, 2012; accepted June 15, 2012 